\title{
Risk factors for Alzheimer's disease
}

\author{
Richard A. Armstrong \\ Vision Sciences, Aston University, Birmingham, United Kingdom
}

\begin{abstract}
Early reviews identified over 20 risk factors associated with Alzheimer's disease (AD) including age, familial inheritance, exposure to aluminium, traumatic brain injury (TBI), and associated co-morbidities such as vascular disease and infection. In the light of recent evidence, this review reconsiders these risk factors, identifies those currently regarded as important, and discusses various hypotheses to explain how they may cause $A D$. Rare forms of early-onset familial $A D$ $(E O-F A D)$ are strongly linked to causal gene mutations, viz. mutations in amyloid precursor protein (APP) and presenilin (PSEN1/2) genes. By contrast, late-onset sporadic AD (LO-SAD) is a multifactorial disorder in which age-related changes, genetic risk factors, such as allelic variation in apolipoprotein $E$ (Apo E) and many other genes, vascular disease, TBI and risk factors associated with diet, the immune system, mitochondrial function, metal exposure, and infection are all implicated. These risk factors may act collectively to cause $A D$ pathology: 1) by promoting the liberation of oxygen free radicals with age, 2) via environmental stress acting on regulatory genes early and later in life ('dual hit' hypothesis), or 3) by increasing the cumulative 'allostatic load' on the body over a lifetime. As a consequence, life-style changes which reduce the impact of these factors may be necessary to lower the risk of $A D$.
\end{abstract}

Key words: Alzheimer's disease (AD), risk factors, aging, genetics, environmental factors, allostatic load.

\section{Introduction}

Early reviews $[74,76,79,80,109]$, and especially that of Henderson [76], identified many of the risk factors associated with dementia in general and Alzheimer's disease (AD) in particular. Over 20 different risk factors associated with $A D$ were discussed by Henderson [76] and a common pathogenesis proposed as to how they might cause the pathological changes characteristic of $A D$, viz. $\beta$-amyloid $(A \beta)$ immunoreactive senile plaques (SP) [57] and tau immunoreactive neurofibrillary tangles (NFT) [59]. More recent research suggests that of the factors discussed by Henderson [76], support for some has increased, others reduced, while new risk factors have also been identified. Hence, in a recent review, over 60 environmental risk factors alone were identified associated with $A D$ and classified into six categories, viz. air quality, heavy metals, other metals, trace elements, occupational exposure, and miscellaneous [101]. It remains a major challenge to explain how many apparently disparate risk factors could contribute to $\mathrm{AD}$.

Historically, the term AD was first used in 1910 by Kraepelin based on the clinical and pathological description of Alzheimer's original cases [8]. Of the two cases originally described by Alzheimer, however, both had numerous SP, but only one had significant numbers of NFT [63], thus identifying the pathological heterogeneity characteristic of AD [14], 
and creating difficulties in establishing a single theory as to its cause [10]. Originally the term AD was applied to early-onset cases only which were regarded as distinct from the more common late-onset cases referred to as 'senile dementia' [76]. It was the discovery of molecular markers associated with $A D$ pathology, viz., $A \beta$ [57] and tau [59], that suggested that pre-senile and senile dementia were essentially subtypes of the same disease. Subsequently, the 'amyloid cascade hypothesis' (ACH) was proposed as a general model of the molecular pathology of $A D$ [72] (Fig. 1). The hypothesis was initially based on the study of early-onset familial AD (EO-FAD) linked to mutations of the amyloid precursor protein (APP) gene and later extended to other genes such as presenilin 1/2 (PSEN1/2), and then to all forms of AD. This hypothesis suggested the deposition of $A \beta$ in the form of SP was the initial pathological event in the disease leading to the formation of NFT, cell death, and ultimately dementia. As a consequence, the significance of a risk factor for $A D$ is often assessed by the degree to which it influences APP metabolism. Nevertheless, the significance of the $\mathrm{ACH}$ as a general model of AD has been questioned [11] and a recent review also identified nine modifiable risk factors for the disease which appeared to act independently of $A \beta$ and tau pathology [117].

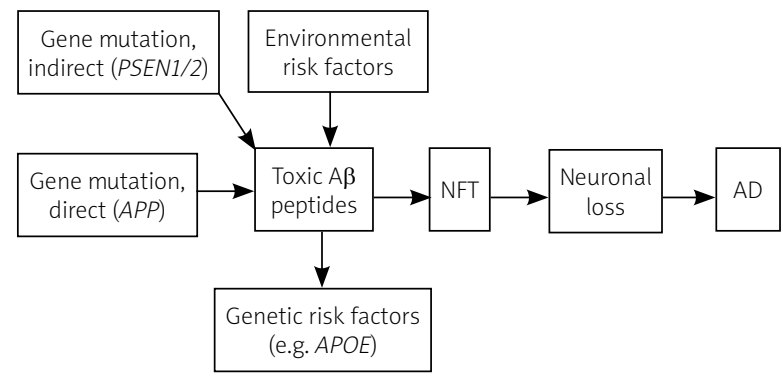

Fig. 1. The 'amyloid cascade hypothesis' (ACH) [72] as a general model of the pathogenesis of Alzheimer's disease (AD). In this scheme the amyloid precursor protein $(A P P)$ gene acts directly, the presenilin (PSEN1/2) genes more indirectly, and together with genetic risk factors such as the apolipoprotein E (APOE) gene and environmental factors, all act to increase the production of toxic $\beta$-amyloid $(A \beta)$ peptides leading to neurofibrillary tangles (NFT), neuronal loss, and ultimately dementia.
Subsequently, many theories have been proposed to explain $A D$, especially the late-onset sporadic form of the disease (LO-SAD), including exacerbation of aging, genetic factors, exposure to aluminium, head injury, diet, mitochondrial dysfunction, vascular disease, immune system dysfunction, and infectious disease [10]. However, no single theory has gained universal acceptance and it has become increasingly recognised that multiple risk factors are likely to be involved. Given recent advances, it would appear timely to update earlier reviews, to reconsider the current state of knowledge regarding the risk factors for $A D$, and to address two questions: 1) to what extent does existing knowledge identify credible risk factors for $A D$ and 2) how can this information be integrated into a hypothesis to explain the pathogenesis of AD? The major risk factors currently considered to be associated with $A D$ are summarised in Table I.

\section{Risk factors \\ Age}

Many epidemiological studies, including those quoted by Henderson [76], agree that of the various demographic factors such as age, gender, race and social class, age is one of the most important risk factors for cognitive decline [43] and AD [78]. With advancing age, the prevalence of $A D$ increases to an estimated $19 \%$ in individuals $75-84$ years of age [103] and to $30-35 \%$, possibly up to $50 \%$ for those older than 85 years [48]. That AD could therefore be an accelerated form of normal aging is largely based on the observation that many of the pathological changes identified in $A D$ are similar, apart from their severity, to those present in normal aging $[154,160]$. Hence, in cognitively normal brain, there is an age-related reduction in brain volume and weight, enlargement of ventricles, and loss of synapses and dendrites in selected areas accompanied by SP and NFT [87]. Hence, a cross-sectional study by Miller et al. [134] investigated changes in density of SP and NFT with age in 199 individuals and observed from age 71, an abrupt increase in the numbers of both lesions. In addition, in 60 normal elderly cases, 32/60 had no SP, although 30/60 were younger than 65 years, $13 / 60$ had SP in the HC, and $12 / 60$ had SP in temporal cortex [121]. It was concluded that it was not possible to distinguish early AD from normal aging at post-mortem [121]. Moreover, in the 
Table I. A summary of risk factors that have been associated with Alzheimer's disease (AD)

\begin{tabular}{|c|c|}
\hline Grouping & Risk factor \\
\hline \multirow[t]{5}{*}{ Demographic } & Age $[43,78,76]$ \\
\hline & Education $[76,92]$ \\
\hline & Gender [76] \\
\hline & Race [76] \\
\hline & Social class [76] \\
\hline \multirow[t]{16}{*}{ Genetics } & Amyloid precursor protein $(A P P)[39,58]^{*}$ \\
\hline & Presenilin 1 and 2 (PSEN1/2) [112,170]* \\
\hline & Apolipoprotein E (APOE) $[110,166,181]$ \\
\hline & $\begin{array}{l}\text { ATP-binding cassette transporter A1 } \\
(A B C A 1)[105]\end{array}$ \\
\hline & $\begin{array}{l}\text { Adaptor protein evolutionarily conserved } \\
\text { signalling intermediate in Toll pathway } \\
(E C S / T)[175]\end{array}$ \\
\hline & Clusterin gene $(C L U)[150]$ \\
\hline & Estrogen receptor gene $(E S R)$ [162] \\
\hline & Fermitin family homolog 2 gene (FERMT2) [38] \\
\hline & $\begin{array}{l}\text { Glyceraldehyde-3-phosphate } \\
\text { dehydrogenase }(G A P D H)[5]\end{array}$ \\
\hline & $\begin{array}{l}\text { Histocompatibility locus antigen } \\
\text { (HLA class III) }[40,77,190]\end{array}$ \\
\hline & mtDNA haplotype [165] \\
\hline & Transferrin gene (Tf) [194] \\
\hline & $\begin{array}{l}\text { Triggering receptor expressed on myeloid } \\
\text { cells } 2 \text { (TREM 2) [161] }\end{array}$ \\
\hline & $\begin{array}{l}\text { Vascular protein sorting-10 domain } \\
\text { (VpS10) genes [108] }\end{array}$ \\
\hline & Vitamin D receptor gene (VDR) [193] \\
\hline & Epigenetic factors $[106,107]$ \\
\hline \multirow[t]{3}{*}{ Lifestyle } & Alcohol [65] \\
\hline & Lack of exercise $[76,102,152]$ \\
\hline & Lack of cognitive activity $[92,174]$ \\
\hline
\end{tabular}

*regarded as causal factors

study of Bergeron et al. [28], SP were observed in $60 \%$ of normal elderly cases, albeit at lower density than in AD. Similarly, Arriagada et al. [15] reported SP in most normal individuals older than 55 years of age suggesting a 'continuum' of pathological change from elderly non-demented brains to early $A D$, and then to advanced AD [9]. In addition, the density of SP with a distinct 'core' ('classic' plaques), were not significantly different in $A D$ and aging [26].

Whether NFT occur in the normal aging brain is more controversial. Some studies suggest that the majority of cognitively normal individuals have low densities of NFT [104] with Braak stages $1 / 2$ being

\begin{tabular}{|c|c|}
\hline \multirow[t]{4}{*}{ Grouping } & Risk factor \\
\hline & Malnutrition $[1,76,189]$ \\
\hline & Poor diet $[65,167,168,176,196]$ \\
\hline & Smoking $[37,76,173]$ \\
\hline \multirow[t]{10}{*}{ Medical } & Cancer [173] \\
\hline & Cardiovascular disease $[76,95,116]$ \\
\hline & Congestive heart failure $[76,81]$ \\
\hline & $\begin{array}{l}\text { Immune system dysfunction } \\
{[12,128,141,158]}\end{array}$ \\
\hline & Micro-infarcts [27] \\
\hline & Obesity $[31,71,125,185]$ \\
\hline & Poor cholesterol homeostasis [110] \\
\hline & $\begin{array}{l}\text { Poorly controlled type-2 diabetes } \\
{[4,118,124]}\end{array}$ \\
\hline & Stroke [203] \\
\hline & $\begin{array}{l}\text { Traumatic brain injury (TBI) }[53,76,80,93, \\
129,130,131,139,169]\end{array}$ \\
\hline \multirow[t]{2}{*}{ Psychiatric } & Depression $[50,21]$ \\
\hline & Early stress $[82,148]$ \\
\hline \multirow[t]{8}{*}{ Environmental } & Air pollution [101] \\
\hline & Calcium deficiency [76] \\
\hline & Geographic location [76] \\
\hline & $\begin{array}{l}\text { Metals (especially aluminium, copper, zinc) } \\
{[16,86,147,156]}\end{array}$ \\
\hline & Military service [60] \\
\hline & Organic solvents [76] \\
\hline & Occupation [101,147] \\
\hline & Vitamin deficiency $[68,126,139]$ \\
\hline \multirow[t]{4}{*}{ Infection } & $\begin{array}{l}\text { Bacteria, e.g. Chlamydophila pneumonia, } \\
\text { Treponema }[19,55,133]\end{array}$ \\
\hline & Dental infections [159] \\
\hline & Fungi [7] \\
\hline & Viruses $[114,164,197]$ \\
\hline
\end{tabular}

characteristic of cognitively normal individuals and higher stages of at least mild cognitive impairment $(\mathrm{MCl})$, and there is also less astrocytosis and microglial reaction [41]. By contrast, Bouras et al. [32] found that all non-demented cases had NFT in layer II of the entorhinal cortex and in sector CA1 of the HC. Moreover, in non-demented individuals, NFT were more numerous in medial temporal lobe (MTL) regions and in cortical association areas when a memory deficit was present suggesting NFT could be related to memory loss in non-demented individuals [70]. In the MTL, the perforant path appears to be especially sensitive to the development of NFT in AD and these changes 
may be distinct from those seen in normal aging even in the oldest individuals [52].

Two further age-related pathological processes may be involved in AD. First, breakdown of myelin and therefore, of white matter fibre tracts [24], although some studies suggest that myelin loss occurs late in the disease secondary to neuronal degeneration [33]. Second, loss of cells occurs in brain stem nuclei such as the locus coeruleus (LC), which provides an input of noradrenaline to the cortex via terminal varicosities and stimulates microglia to suppress production of A $\beta$ [75]. NFT appear early in the $L C$ as a result of aging, $M C l$, and in $A D$ [69]. Loss of cells in the LC may therefore induce an age-related impairment of the blood-brain barrier (BBB), thus implicating age-related vascular factors in $\operatorname{AD}[95,120]$.

\section{Genes}

Despite problems in interpreting early studies of familial cases, including biased recall by relatives and the identity of the actual disorders involved, there was consistent evidence that first-degree relatives of AD patients had themselves an increased risk of dementia [76]. That the degree of the genetic link also varied among individuals was emphasised in an early study by Heyman et al. [79] who reported that late-onset cases had a risk of a family history no more than the general population and that a substantial number of cases were not likely to have a primary genetic basis. When Henderson's [76] review was published, however, there were no data on the specific genes likely to be involved in AD. Subsequently, a small number of genes have been identified as causal and many others as possible risk factors.

\section{APP}

In the early 1990s, strong evidence emerged of the connection between some rare forms of EO-FAD and specific genetic factors, small numbers of cases being linked to mutations of the APP gene $[39,58]$. Cleavage of $A P P$ results in the formation of a variety of $A \beta$ peptides [67], the most common being $A b_{1-42}$, found largely in SP, whereas the more soluble $A b_{1-40}$ is also found in association with cerebral micro-ves sels [135] and may develop later in the disease [42]. In addition, mutations of $A P P$ within the $A \beta$ coding region may result in the deposition of $A b_{1-38}$ in ves- sel walls, especially in cases with extensive cerebral amyloid angiopathy (CAA) [138]. Early soluble peptide oligomers could also be involved [56], which vary with the type of mutant, thus providing a genetic basis for variations in pathogenesis in FAD. The discovery of $A \beta$ led ultimately to the ACH [72] (Fig. 1) and therefore, risk factors which modify APP metabolism have been given considerable prominence in AD. For example, genome-wide association studies (GWAS) report large numbers of genes with a functional impact on APP, with at least 832 genes having the property of moderating APP metabolism, eight of which occur within known AD susceptible loci [38]. These genes include the 'fermitin family homolog 2 gene' (FERMT2), a $\beta$-3-integrin co-activator, which is significantly associated with variations in $A \beta$ in cerebral spinal fluid (CSF) [38]. Under-expression of this gene may elevate $A \beta$ by raising the level of mature APP and facilitating its recycling at the cell surface. In addition, ATP-binding cassette transporter $A 1$ ( $A B C A 1)$ gene may have a role in $A \beta$ deposition and clearance and may be associated with some variants of AD [105].

\section{PSEN1/2}

The most common form of EO-FAD is associated with mutations of the PSEN $1 / 2$ genes $[112,170]$. Full length PSEN is composed of nine trans-membrane domains located on the endoplasmic reticulum. Endoproteolytic cleavage of PSEN and assembly into $\gamma$-secretase complex is followed by transport to the cell surface, thus potentially influencing APP processing [85]. Mutant PSEN1 may interact with APP by enhancing 42 -specific- $\gamma$-secretase cleavage of normal APP resulting in increased deposition of $A \beta$ [182]. Nevertheless, PSEN may have a variety of other functions. First, it may act via loss of function by a reduction in $\gamma$-secretase activity [199]. Second, the PSEN1 gene may be involved in notch signalling and may therefore be important in cell differentiation [179]. Third, PSEN1/2 may be involved via the perturbation of cellular calcium homeostasis [202] or in interactions with the transcriptional coactivator CAMP-response element binding (CREB-binding) protein which plays a key role in regulating gene expression [49]. Fourth, PSEN1 may mediate neuroprotective functions by ephrin-B [23] and a decline in such protection could be involved in AD. Hence, there may be features of the action of PSEN1 not directly related to APP metabolism. 


\section{APOE}

Several studies have emphasised the importance of genes involved in cholesterol transfer as risk factors for $\mathrm{AD}$ such as apolipoprotein $E(A P O E)$, apolipoprotein C1 (APOC1), and apolipoprotein J (APOJ) (clusterin) suggesting deterioration of cholesterol homeostasis [110]. Allelic variation in the APOE gene is a major risk factor in $S A D$, individuals with $A D$ having 2-3 times the frequency of allele $\varepsilon 4$ compared with normal control cases $[166,181]$. In addition, the presence of $\varepsilon 4$ may directly affect cognitive function being associated with reduced test scores on adult learning tasks involving memory and learning [116]. Allele $\varepsilon 4$ may accelerate the development of $A D$ pathology within the aging brain [143] and hence, is often associated with an earlier disease onset [61]. The majority of studies also report increased $A \beta$ deposition in individuals expressing $\varepsilon 4[25,29,149]$. In addition, peripheral inflammation, APOE and $A \beta$ may interact to induce cognitive decline and cerebrovascular dysfunction [123] and in transgenic mice, ¿4 markedly facilitates age-dependent CAA [51].

\section{Other genes}

APP and PSEN $1 / 2$ genes together account for less than $5 \%$ of all AD cases $[66,83]$. Hence, GWAS have also revealed $A D$-associated genes on chromosomes $6,9,10,11,12,14,18,19$ [34,172]. The gene on chromosome 12 [145] was mapped to $12 q 13$, a region which encompasses the vitamin $D$ receptor $(V D R)$ gene [193]. This gene is a major mediator of the activity of vitamin $D$ and insufficiency of this vitamin could therefore be linked to AD. In addition, a gene polymorphism at 9p21.3 may affect susceptibility to $A D$ in Caucasians [201]. A more recent GWAS indicates 26 novel risk factor genes involving a variety of functions including cholesterol and lipid metabolism, the immune response, and endocytic trafficking [99]. Additional genes which have been reported as possible risk factors include glyceraldehyde-3-phosphate dehydrogenase (GAPDH) [5], a rare variant of the triggering receptor expressed on myeloid cells 2 (TREM2) gene [161], genetic variation in the estrogen receptor (ESR) gene [162], polymorphisms of the clusterin gene [150], and the transferrin (Tf) gene [194]. The TREM2 gene is involved in triggering receptor expression on myeloid cells, and upregulation of the gene has been demonstrated in frontal cortex but not in the HC in SAD [146].

\section{Epigenetic factors}

Epigenetic factors, i.e., heritable changes in gene expression which do not involve DNA coding sequences, have also been identified which may alter allelic expression in a significant number of the genes involved in AD [106]. Hence, Lahiri and Maloney [107] have proposed a 'dual hit' hypothesis in which epigenetic changes early and later in life summate to result in AD, a hypothesis which will be described in more detail in a later section.

\section{Metals}

Virtually the only metal considered by earlier reviews as a risk factor for AD was aluminium, exposure to which was considered then, and remains today, controversial $[10,12,13]$. Since the 1980 s, there has been more general concern regarding metal exposure as the ability of cells to efficiently maintain key processes with age, such as energy production, repair, and regeneration, is dependent on a range of metals [156]. In addition, a significant proportion of the population are routinely exposed to trace metals such as aluminium, lead, iron, and copper, obtained from a variety of sources, and all are potential risk factors for AD [86]. Arsene et al. [16], however, reported no relationship between metal accumulation with age or neurodegeneration suggesting the brain was not a favourable site for metal accumulation.

Recent data suggest that: 1) a large number of metals could be implicated in $A D$ pathogenesis, 2) there may be interactions among different metals, and 3) metal imbalance leading to lack of cellular homeostasis could be an important factor. Regarding the individual metals, more recent studies of aluminium report significantly increased mortality from $A D$ among miners exposed to aluminium-rich dust [147] suggesting that some aspects of this hypothesis might be worth revisiting. In addition to aluminium [195], zinc [127,192], mercury [140], copper [86,144], manganese [45,186], cadmium [136,142], and magnesium [188] have all been suggested as risk factors for AD. Many of these metals have been shown to interact directly with APP metabolism or with APOE [140]. Studies have also emphasised the synergistic effects of different metals. Hence, a mixture of arsenic, cadmium, and lead increased $\mathrm{A} \beta$ deposition in frontal cortex and $\mathrm{HC}$ in young rats by increasing APP and activating the pro-amyloidogenic pathway [17]. However, realistic intakes of 
a mixture of aluminium and zinc did not accelerate AD-type pathology in a double transgenic mouse model (APP, tau) [3]. A key process which becomes dysregulated with age is metal homeostasis [2] and imbalances among essential trace elements together with exposure to other metal ions, may result in $A D$ pathology. Hence, AD plasma/serum and brain is characterised by lack of homeostasis among zinc, copper, and iron all of which are involved in the regulation of APP/tau and also interact with APOE [200].

\section{Traumatic brain injury}

Henderson [76] quoted three studies suggesting increased frequency of traumatic brain injury (TBI) in the previous history of AD patients $[80,139,169]$. TBI could cause damage to the $B B B$ resulting in leakage of plasma proteins and sensitization of the immune system to brain antigens normally isolated from them. Subsequently, a number of studies reported a connection between head injury and AD. In survivors of head injury, APP is observed in neuronal cell bodies and in dystrophic neurites surrounding A deposits, as observed in AD [54]. Subsequently, it was shown that specific neurons in the medial temporal lobe (MTL) secreted large quantities of APP and that there were more APP-immunoreactive neurons in these areas in TBI [132]. Hence, increased expression of APP in head trauma cases may be an acute-phase response to neuronal injury [156], the overexpression of APP leading to the deposition of $A \beta$. Several acute-phase proteins are localised within $A \beta$ deposits in $A D$ including amyloid-P, complement factors, and $\alpha$-antichymotrypsin [96]. Furthermore, Regland and Gottfries [153] proposed that APP maintains cell function by supporting neuronal growth and survival. The possible neurotrophic action of APP is also supported by the observation that it shares structural features with the precursor for the epidermal growth factor. Moreover, NFT may be part of the neurons response to injury [198].

The relationship between $T B I$ and $A D$ is further emphasised by the discovery of the tauopathy chronic traumatic encephalopathy (CTE), a neurodegenerative disorder believed to result directly from repetitive brain injury $[53,93]$. Hence, CTE has been recorded in association with contact sports including boxing, American football, ice hockey, and wrestling [122] and has also been reported in military veterans exposed to blast shock waves from explosive devices $[60,129,130,171]$. Clinically, the symptoms of CTE resemble those of $A D$ and include impairment of memory and executive function, behavioural change, disturbances of mood, and the presence of motor symptoms $[163,180]$. The neuropathology of CTE also overlaps with that of AD [122]. Hence, CTE cases exhibit reduced grey matter volume in several brain regions, most prominently the frontal and anterior temporal lobes associated with enlargement of the lateral and third ventricles $[129,131]$. CTE as a tauopathy has a spectrum of tau-immunoreactive pathology which varies from focal, perivascular NFT in frontal cortex [100] to a more widespread and severe tauopathy affecting temporal lobe, limbic system, and the striato-nigral system [129]. The isoform profile and phosphorylation state of tau in CTE is also similar to that of $A D$ in that both three-repeat (3R) and fourrepeat (4R) tau are present in equal ratios [204]. NFT and neuropil threads (NT) can be observed in affected areas together with comorbid AD neuropathologic change (ADNC) in the form of $A \beta$ deposits [64,91], and astrocytic tangles (AT) $[163,177]$. Whether CTE is a distinct tauopathy or a subtype of AD linked specifically to head trauma remains to be established.

\section{Diet}

Apart from malnutrition and calcium deficiency, dietary-related factors were not particularly emphasised in earlier reviews $[74,76,79,80,109]$. Nevertheless, more recent research has identified a number of such factors for $A D$ and specifically the importance of obesity, variation in diet, and diabetes.

\section{Malnutrition}

Abalan [1] was one of the first investigators to propose that malnutrition could be a risk factor for $A D$. This hypothesis was based on clinical observation of $A D$ patients who often exhibited emaciation and cachexia, urinary tract infections, terminal bronchopneumonia, and low triceps skinfold. Low serum albumin, iron, folate, tryptophan, vitamin B12, and cerebral metabolism of glucose and oxygen were also present. These symptoms suggest a 'protein-calorie malnutrition syndrome' in AD which could result in the development of NFT due to a chronic nutritional deficiency of calcium/magnesium. In addition, marked deficiency of vitamins $E, A, D$, and $K$ has been observed in plasma in $A D$ suggesting that regular supplements might enhance cognition and reduce $A \beta$ deposition 
[68]. A problem with this type of hypothesis, however, is in separating cause and effect, as malnutrition or various deficiencies might also be the consequence of $A D$, viz., resulting from either the mental state of the patient or physiological changes within the body secondary to $A D[1]$.

\section{Variation in diet}

One of the first demonstrations of a link between diet and AD was by Sparks et al. [176] in which deposition of $A \beta$ was induced in rabbits fed with high levels of dietary cholesterol. Moreover, although dietary cholesterol does not normally cross the BBB, in cholesterol-fed rabbits, both enlarged ventricles and a reduction in cerebral vessels were observed [168]. Using a triple transgenic mouse model, high fat consumption combined with a lower polyunsaturated fatty acid ratio also promoted $A \beta$ and a tau-immunoreactive pathology similar to that of AD [94]. Moreover, statin use may reduce the risk of $A D$ independent of the possession of $A P O E$ allele $\varepsilon 4$, but the strength of this link reduces with age $[113,126]$. McCaddon and Kelly [126] found in a human family carrying an $A P P_{717}$ mutation, that individuals with $A D$ had a greater vitamin B12 deficiency compared with unaffected members. This link was unlikely to be a consequence of impaired dietary intake; additional evidence that vitamin B12 deficiency could be a risk factor for AD. There is also evidence that vitamin $\mathrm{D}$ deficiency and consequent homocysteinemia could influence both the progression of neurodegeneration and the degree of vascular pathology [137]. Hence, in dementia cases, vitamin D deficiency, low levels of folate, and high levels of homocysteinemia were more pronounced in cases with subcortical vascular dementia $(\mathrm{VaD})$. The synergistic effects of malnutrition, oxidative stress and homocysteine-related vitamins in AD were also emphasised by von Arnim et al. [189]. Nevertheless, the impact of nutritional supplements in early and late AD using B-vitamins and antioxidant vitamins has been inconclusive. Wang et al. [196] studied the influence of diet and cognitive function in individuals with $\mathrm{MCl}$ in a large cohort of Chinese patients and revealed a link between inadequate consumption of legumes and animal oil, other food items having no significant association.

\section{Obesity}

Whether obesity is a specific risk factor for $A D$ has been controversial. Of 14 different risk factors associated with cognitive impairment in a large sample of cases, depression, obesity, and hypercholesterolemia were more likely to be associated with a low $A D$ risk, only alcohol use increasing the risk of cognitive decline [31]. The study also concluded that many of the 'traditional' risk factors for $A D$ were not associated with early $A D$ or its progression. By contrast, a strong correlation between obesity and the development of AD has been observed suggesting that metabolic changes associated with obesity damage the nervous system leading to neuronal death by apoptosis or necrosis by altering the plasticity of neurons [125]. Obesity has been consistently associated with the presence of dementia, higher midlife body mass index (BMI) proportionally increasing AD risk [185]. Moreover, obesity in combination with vascular risk factors was associated with LO-SAD and with various metabolic syndromes involving leptin and adiponectin expression [71].

\section{Diabetes}

Insulin has a central role as a neuromodulator [98] and therefore, it is not surprising that diabetes has been linked to AD [4]. First, there is an association between hyperinsulinemia and hyperglycaemia and $A D$, which is caused by insulin resistance resulting in accumulating SP especially in individuals expressing APOE allele $\varepsilon 4$ [124]. Second, there is a link between type 2 (T2) diabetes and its precursors, elevated adiposity and hyperinsulinemia, and dementia; the risk evident in middle-aged, but not in older individuals, and greater for $\mathrm{VaD}$ than LO-SAD [118]. Third, in transgenic APP/PS1 mice with severe hyperinsulinemia there was severe brain atrophy, cortical thinning, and elevated caspase levels [151]. Fourth, in experiments using rats fed a high fat diet including cholesterol, there was an increased cognitive decline accompanied by $A \beta$ deposition in the $\mathrm{HC}$ [22]. Fifth, there is an association in diabetics between diabetes-associated genes within the sortitin family of vascular protein sorting-10 domain (VpS10) genes and $A D$, dysfunction of which can lead to $A \beta$ deposition and insulin/glucose dysfunction [108].

\section{Mitochondrial dysfunction}

Although not discussed specifically by Henderson [76], theories suggesting that mitochondrial dysfunction may be involved in AD have a long history [30]. Hence, distorted mitochondria accompanied 
by a decline in cerebral metabolic rate are present in early $A D$ [30]. In addition, there is a deficiency of enzymes involved in carbohydrate utilization including such mitochondrial markers as phosphofructokinase (PFK) and pyruvate dehydrogenase [30]. As a consequence, chronic hypoperfusion could induce oxygen stress via the production of reactive oxygen species (ROS) and result in mitochondrial failure and $A D$ [6]. Moreover, part of the familial aggregation of $A D$ may reflect excess maternal versus paternal inheritance consistent with mitochondrial inheritance. The possibility of a genetic origin of mitochondrial dysfunction in AD has also led to the formulation of a 'mitochondrial cascade hypothesis' $(\mathrm{MCH})$, in which it is mitochondrial dysfunction that is the initial event leading to AD pathology [183]. A particularly interesting protein is 'adaptor protein evolutionarily conserved signalling intermediate in Toll pathway' (ECSIT) which may act as a molecular sensor, involved in a cell homeostasis in response to oxidative damage by $A \beta$ [175]. Protective molecules could then be specifically activated in response and this failure could result in severe mitochondrial damage, promoting apoptosis, and resulting in synaptic dysfunction and neuronal death [175]. A correlation has also been observed between mitochondrial DNA (mtDNA) haplotype and AD, the sub-haplogroup $\mathrm{H} 5$ of mtDNA being a risk factor for LO-SAD [165].

\section{Vascular disease}

Henderson [76] noted that AD and VaD commonly coexist, $18 \%$ of a dementia autopsy series having evidence of both disorders. If $A D$ and $V a D$ are distinct and independent disorders, then the prevalence of their joint occurrence should be the product of their respective prevalence ratios [76]. Nevertheless, the observed prevalence of $A D / V a D$ is usually greater than indicated by this calculation suggesting either that the effects of mild $A D$ and $V a D$ are additive thus increasing the chance of recognition of their joint occurrence or that the ischaemia of $\mathrm{VaD}$ accelerates the pathogenesis of AD [76].

Many studies have identified a number of links between AD and cardiovascular disease (CVD) [116]. The integrity of the vascular system is essential for normal brain function and age-related changes in the vasculature result in impairment of autoregulation, neovascular coupling, BBB leakage, and reduced vascular tone [95]. These changes may precede cognitive decline and in combination with other factors contribute to the neuropathology of AD [95]. Various vascular factors have been correlated collectively with the assessed neuropsychology of $A D$, but no individual vascular risk factor could predict change in any single neuropsychological feature [178]. In addition, various biomarkers of microvascular endothelial dysfunction are associated with dementia including elevated levels of the vasodilator peptide hormone mid-regional proadrenomedullin (MR-proADM) which is present in all forms of dementia while elevated C-terminal endothelin-1 (CT-proET-1) is only associated with VaD [84].

CVD may result in $A \beta$ deposition and affect the age of onset of $A D$ while $A \beta$ may itself trigger cardiovascular degeneration [111]. Individuals with congestive heart failure also have a higher risk of dementia [81] while cerebral ischaemia and stroke may lead to hypoxia, $A \beta$ deposition, and impairment of the BBB leading to neuronal degeneration [203]. Small infarcts and micro-bleeds are also associated with increasing $A \beta$ deposition [27]. Finally, blood vessels with collapsed or degenerated endothelia are evident in more than $90 \%$ of $A D$ cases [97] and occur concurrently with $A \beta$ deposition while blood vessels exhibit degenerative changes in $A D$ accompanied by $A \beta$ deposition and loss of smooth muscle cells [184]. Attems et al. [18] found additionally that $A \beta_{42}$ was deposited within the glia limitans rather than capillary walls.

\section{Immune system}

Various disorders and co-morbidities associated with $A D$ were discussed in earlier reviews [76] but there was little specific discussion of the involvement of the immune system. Nevertheless, several lines of evidence support the presence of immune system dysfunction in AD $[128,141,158]$. Hence, complement proteins associated with the 'classical' pathway [141], brain reactive antibodies [128], immunoglobulins $[46,88]$, circulating immune complexes (CIC) in peripheral tissue and cerebral blood vessels [73], helper/inducer and cytotoxic/suppressor T-cells [128], and abundant reactive microglia [128] have all been observed in AD. Complement system proteins may act as pattern recognition molecules mediating the uptake of $A \beta$ by glial cells, which express complement receptors [187]. In addition, alterations in the major histocompatibility locus (MHC) antigens 
have been demonstrated [190] suggesting either increased resistance or susceptibility to a specific antigen in AD [40,77]. Several genes encoding the inflammatory mediators have also been implicated in AD, especially those of HLA class III region [119]. Nevertheless, it is unclear whether the immune response is a reaction to a primary antigen or a secondary response to the deposition of the characteristic AD proteins.

\section{Infectious agents}

The possible involvement of infectious agents in $A D$ has long been suggested as a risk factor [89] and the possibility of virus infection was also discussed by Henderson [76]. One of the first studies to suggest that infection could be a risk factor for AD proposed that invasion by herpes simplex virus (HSV), to which antibodies may be observed in cerebral spinal fluid (CSF) in AD, could induce abnormal protein formation resulting in NFT [114]. In addition, invasion by a virus may activate microglia and pericytes ultimately resulting in $A \beta$ deposition [197]. Such a theory is given further credibility by observations of marked structural and biochemical alterations in regions of the $A D$ brain associated with olfaction, most notably the olfactory bulb and entorhinal cortex [44], the olfactory system being a possible point of entry into the brain for an infectious agent or protein [121]. Hence, viruses introduced into body cavities and organs often result in high titres of the virus in olfactory epithelium, olfactory bulb, and other brain regions. Nevertheless, HSV does not typically enter the brain via the olfactory system [164]. More recently, however, DNA from peripheral blood leucocytes and brain of AD patients has been analysed for cytomegalovirus (CMV), Epstein-Barr virus (EBS), and human herpes virus 6 (HHV-6), the data suggesting that EPV and HHV-6 could be risk factors for cognitive decline and progression to AD [35]. In addition, dental infections could be a risk factor [159], a higher prevalence of the disease being observed in those patients with orofacial pain and periodontal infection although these effects could also be secondary to $A D$. No increase in the incidence of pneumonia has been reported in SDAT although the Chlamydophila pneumoniae bacteria are implicated in LO-SAD [19] and associated with AD pathology [55]. In addition, there are clinical and pathological similarities between syphilitic dementia caused by
Treponema bacteria and AD [133] and evidence that $A \beta$ may be an 'anti-microbial' peptide [62]. Fungi have also been suggested as a risk factor for AD [7].

\section{Psychiatric factors}

The role of psychiatric factors as antecedents to AD was discussed by Henderson [76] who reported negative results from various studies $[74,109,173]$. Nevertheless, Heyman et al. [80] reported that a previous psychiatric morbidity was associated with $A D$ while French et al. [50] and Barclay et al. [21] both suggested an association with depression. Subsequently, Bannerjee et al. [20] investigated whether such associations were due to depression either being a risk factor or a co-morbidity of AD. It was concluded that the coexistence of the two conditions could reflect altered circulating levels of common metabolites such as cytokine $\mathrm{K} 6, \mathrm{TNF}-\alpha$, and serum 25 hydroxy-vitamin D. Increasing stress in early life has also been suggested as a risk factor for cognitive decline at a later age with evidence that stress may contribute to amyloid pathology in early stressed mice [82]. Piirainen et al. [148] also emphasises that chronic psycho-social stress should be recognised as a risk factor for LO-SAD.

\section{Discussion}

\section{What are the major risk factors for Alzheimer's disease?}

As earlier reviews concluded, there are large numbers of potential and apparently unrelated risk factors associated with AD. That there is a clear association between $A D$ and aging was widely accepted by earlier investigators and is still valid today [155], many of the features of $A D$ pathology being observed to some extent in the aging but cognitively normal brain [154]. In addition, in rodent models of $A D$, the most important factors influencing the onset of 'AD' are often age-related including: 1) perturbation of ribosomal and oxidative phosphorylation pathways, 2) changes in genes associated with hypothalamic-pituitary-adrenal function, and 3) changes in insulin signalling [90]. Although Henderson [76] discussed family history as a factor, there was little genetic information available at that time. Subsequently, large numbers of genes have been identified in AD, either causal as in EO-FAD such as APP [39,58] and PSEN1/2 [112,170] or associated as risk factors with LO-SAD as a result of GWAS [99], 
allelic variation of the $A P O E$ gene $[166,181]$ being the most significant to date. Moreover, the case for head injury as a risk factor has been strengthened by the discovery of the tauopathy CTE although its relationship to $A D$ is unclear [129-131]. Vascular factors continue to be an important element of the risk supported by many pathological studies of the vasculature [95]. New risk factors have also been identified including those associated with diet such as obesity $[31,71,125,185]$, diabetes $[4,118,124]$ and factors associated with the immune system $[12,128,141,158]$. With reference to metal exposure, the case for aluminium is less strong but other metals such as zinc and copper have been implicated, and the interactions among different metals emphasised $[16,86,147,156]$. Recent data have also increased the probability that exposure to infectious agents could be involved [89].

\section{How do risk factors result in Alzheimer's disease pathology?}

The challenge posed by these data is the same as that discussed by Henderson [76], viz. how to integrate the epidemiological findings to demonstrate how numerous and disparate risk factors result in AD. The study of risk factors suggests that, with the exception of some rare EO-FAD cases, AD is not primarily a disease linked directly to defective genes but a complex syndrome dependent on the rate of aging and indirectly influenced by many genetic and environmental risk factors and the general health of the patient [101]. In fact any factor which influences the health of an individual through life and the rate of aging could be a potential risk factor.
A number of attempts have been made to formulate hypotheses to explain $A D$ based on risk factors and this review considers three possible approaches to the problem. First, in his synthesis of epidemiological findings, Henderson [76] suggested either: 1) "an accumulation of some toxic substance or a time-dependent effect following prior introduction of a toxic substance or infectious particle" or 2) "an age-related increase in a biological process necessary for normal neuronal function accentuated by environmental exposure and/or genetic vulnerability". It was also concluded that it was unlikely that genetic or environmental factors act directly but that they accentuate some general process that occurs in the brain with age. It was postulated that the common feature associated with many of the risk factors is that they act by promoting the increasing liberation of oxygen free radicals with age which then exacerbate the rate of normal aging ultimately resulting in $\mathrm{AD}$ (Fig. 2).

Second, Lahiri and Maloney [107] proposed a 'dual hit' hypothesis to explain AD (Fig. 3), which involves the latent expression of specific genes triggered at the developmental stages of life. Hence, the first 'hit' involves environmental stress early in life acting on gene regulation at sites of promoter genes and mediated by epigenetic changes such as DNA methylation. The second 'hit' involves further stress acting later in life in combination with changes in gene expression. In this hypothesis, it is the interaction between environmental stress, which may involve many disparate risk factors, and genes which is emphasised.

A third hypothesis is based on the concept of the body's 'allostatic load' (Fig. 4) [10,36]. The primary

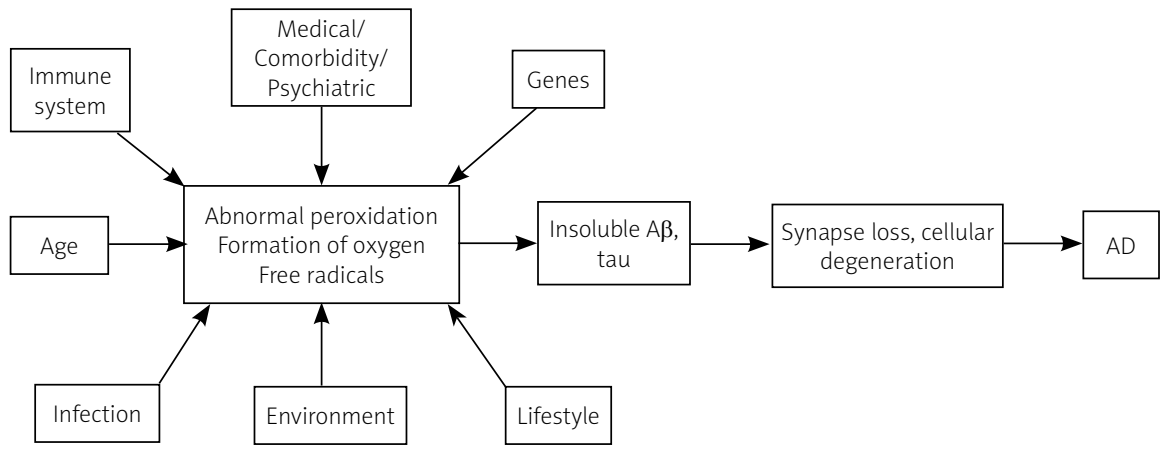

Fig. 2. A scheme based on Henderson's hypothesis [76]. Hence, genetic or environmental factors promote the increasing liberation of oxygen free radicals with age which then exacerbate the rate of normal aging. 
risk factor in this scheme is the rate of aging, the age dependent breakdown of anatomical systems, and consequent loss of synapses [36]. The extent of this aging effect, which begins early in life, is mediated by the degree of lifetime stress or allostatic load [36]. The brain is the ultimate mediator of stress-related mortality through hormonal changes resulting in hypertension, glucose intolerance, CVD, and immunological problems [36]. The consequence of these processes is gradual synaptic disconnection, neuronal degeneration, and the upregulation of genes which determine the production of reactive and breakdown products such as $A \beta$ and tau $[153,191]$.

\section{How could the risk of Alzheimer's disease be reduced?}

An inevitable conclusion from the study of $A D$ risk factors and the hypotheses they suggest is that life-style changes need to be implemented over a life-time to significantly reduce the risk of $A D$. Hence, strategies are required that will slow the rate of aging by reducing the allostatic load. For example, healthy fit middle-age adults tend to have fewer chronic conditions later in life and therefore, a lesser burden of chronic disease before death [152]. It has also been suggested that physical exercise can modify metabolism, brain processes, and preserve cognition if suitable structured exercise programs could be developed which are specific to the individual, of sufficient intensity and duration, and which comprise several different components [102]. There is also growing evidence that increased cognitive activity through life could reduce the risk of $A D[92,174]$. Three factors may influence cognitive performance

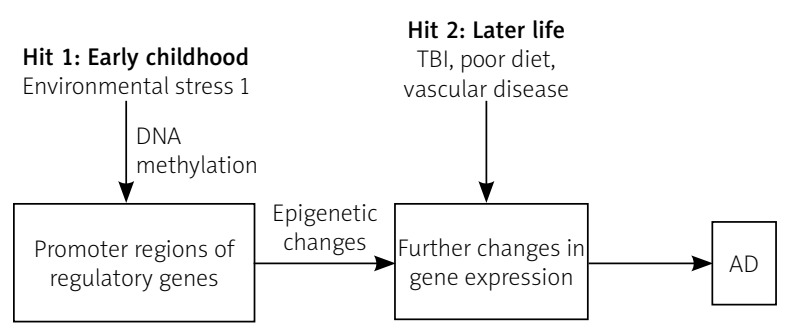

$A D$ - Alzheimer's disease, $T B \mathrm{~B}$ - traumatic brain injury

Fig. 3. The 'dual hit hypothesis' [107] which involves the latent expression of specific genes triggered at the developmental stages of life. Hit 1 involves environmental stress early in life acting on gene regulation at sites of promoter genes and mediated by epigenetic changes such as DNA methylation while hit 2 involves further stress acting later in life in combination with changes in gene expression.

in later life: 1) the level of education, 2) occupational complexity, and 3) the degree of cognitive leisure activity [92]. In a study of the effect of these variables on cognitive performance of middle-aged adults at risk of $A D$, it was shown that some of the variance attributed to education was closely related to the degree of cognitive activity [92].

Evidence that dietary changes can reduce the risk of $A D$ has been more controversial. In Japan, for example, the rate of $A D$ has risen markedly in the last decade associated with increased consumption of alcohol and animal products and a reduction in 'traditional' diets [65]. There has also been interest in whether the 'Mediterranean' diet, i.e., a diet rich in vegetables, fruits, fish, and olive oil may be

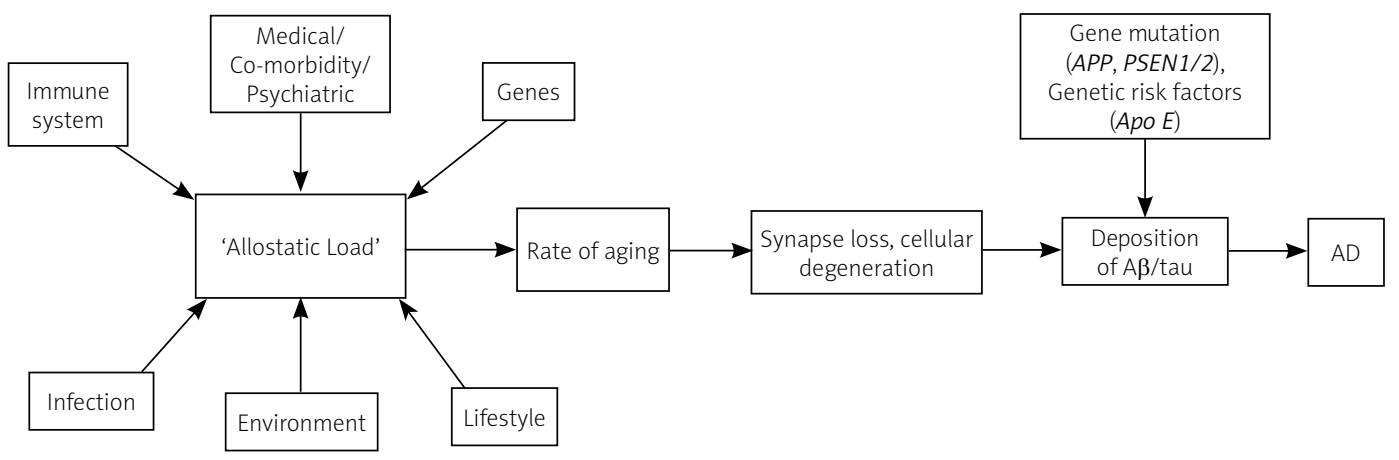

Fig. 4. A scheme of how the various risk factors may cause Alzheimer's disease (AD) based on the allostatic load $[10,36]$. The various risk factors act cumulatively and in combination to increase the rate of normal aging, leading to degeneration of neural pathways and blood vessels and resulting in the formation of $\beta$-amyloid (A $\beta$ ) and tau and then senile plaques (SP) and neurofibrillary tangles (NFT). 
protective against AD. Hence, Scarmeas et al. [167] in a study involving 2000 participants evaluated every 18 months, showed that those with a higher 'commitment' to the Mediterranean diet exhibited a reduced cognitive decline. In the 'Rotterdam study' involving 5000 participants and followed up after 6 years, a diet high in antioxidants including $\beta$-carotene, flavonoids, vitamin $C$, and vitamin $E$ was associated with reduced AD incidence [47]. There is no current evidence that cessation of smoking reduces the risk of AD. Nevertheless, smoking is regarded as a risk factor for many chronic diseases and is likely to contribute significantly to the allostatic load, although its specific effects on the brain are unclear [37].

In conclusion, many risk factors have been associated with $A D$ including those related to on aging, genes, metals, TBI, diet, vascular factors, the immune system, and exposure to infectious agents. With the exception of some rare EO-FAD cases, AD is a multifactorial disorder in which the effect of external and internal risk factors act collectively to affect common processes such as oxygen free radical generation, gene regulation, or the allostatic load. These processes result in an acceleration of the rate of aging that is the ultimate cause of AD. Life-style changes which act to reduce the impact of these processes is therefore a credible strategy to slow the rate of aging and the risk of AD.

\section{Disclosure}

\section{The author reports no conflict of interest.}

\section{References}

1. Abalan F. Alzheimer's disease and malnutrition: a new aetiological hypothesis. Med Hypotheses 1984; 15: 385-393.

2. Adlard PA, Bush Al. Metals and Alzheimer's disease: How far have we come in the clinic? J Alzheimers Dis 2018; 62: 1369. 1379.

3. Akiyama H, Hosokawa M, Kametani F, Kondo H, Chiba M, Fukushima M, Tabira T. Long-term oral intake of aluminium or zinc does not accelerate Alzheimer pathology in AssPP and AssPP/tau transgenic mice. Neuropathology 2012; 32: 390-397.

4. Akter K, Lanza E, Martin S, Myronyuk N, Rua M, Raffa R. Diabetes mellitus and Alzheimer's disease: shared pathology and treatment? Br J Clin Pharmacol 2011; 71: 365-376.

5. Allen M, Cox C, Belbin O, Ma L, Bisceglio GD, Wilcox SL, Howell CC, Hunter TA, Culley O, Walker LP, Carrasquillo MM, Dickson DW, Petersen RC, Graff-Radford NR, Younkin SG, Ertekin-Taner N. Association and heterogeneity at the GAPDH locus in Alzheimer's disease. Neurobiol Aging 2012; 33: 203.e25-33.
6. Aliev G, Palacios HH, Walrafen B, Lipsitt AE, Obrenovich ME, Morales $L$. Brain mitochondria as a primary target in the development of treatment strategies for Alzheimer's disease. Int J Biochem Cell B 2009; 41: 1989-2004.

7. Alonso R, Marina D, Morato A, Rábano E, Carrasco A, Pisa L. Fungal infection in patients with Alzheimer's disease. J Alzheimers Dis 2014; 41: 301-311.

8. Alzheimer A. On a peculiar disease of the cerebral cortex. Allg Z Psychiatr PS 1907; 64: 146-148.

9. Armstrong RA. $\beta$-amyloid $(A \beta)$ deposition in cognitively normal brain, dementia with Lewy bodies, and Alzheimer's disease: a study using principal components analysis (PCA). Folia Neuropathol 2012; 50: 130-139.

10. Armstrong RA. What causes Alzheimer's disease? Folia Neuropathol 2013; 51: 169-188.

11. Armstrong RA. A critical analysis of the 'amyloid cascade hypothesis'. Folia Neuropathol 2014; 52: 211-225.

12. Armstrong RA, Winsper SJ, Blair JA. Hypothesis: is Alzheimer's disease a metal-induced immune disorder? Neurodegeneration 1995; 4: 107-111.

13. Armstrong RA, Winsper SJ, Blair JA. Aluminium and Alzheimer's disease: Review of possible pathogenic mechanisms. Demen Geriatr Cogn 1996; 7: 1-9.

14. Armstrong RA, Nochlin D, Bird TD. Neuropathological heterogeneity in Alzheimer's disease: A study of 80 cases using principal components analysis. Neuropathology 2000; 20: 31-37.

15. Arriagada PV, Marzloff K, Hyman BT. Distribution of Alzheimer-type pathologic changes in non-demented elderly individuals matches the pattern in Alzheimer's disease. Neurology 1992; 42: 1681-1688.

16. Arsene D, Preoteasa V, Petrescu A, Balan A, Ardeleanu C. Trace metals as factors in human neurodegeneration: real role or random association: An Autopsy study. Trace Elem Electroly 2011; 28: 221-231.

17. Ashok A, Rai NK, Tripathi S, Bandyopadhyay S. Exposure to As-, $\mathrm{Cd}$-, and Pb-mixture induces A beta, amyloidogenic APP-processing and cognitive impairments via oxidative stress-dependent neuroinflammation in young rats. Toxicol Sci 2015; 143 : 64-80.

18. Attems J, Lintner F, Jellinger K. Amyloid beta peptide 1-42 highly correlates with capillary cerebral amyloid angiopathy and Alzheimer disease pathology. Acta Neuropathol 2004; 107: 283291.

19. Balin B, Gérard H, Arking E, Appelt D, Branigan P, Abrams J, Whittum-Hudson J, Hudson A. Identification and localization of Chlamydia pneumoniae in the Alzheimer's brain. Med Microbiol Immun 1998; 187: 23-42.

20. Banerjee A, Khemka VK, Roy D, Dhar A, Roy TKS, Biswas A, Mukhopadhyay B, Chakrabarti S. Role of pro-inflammatory cytokines and vitamin D in probable Alzheimer's disease and depression. Aging Dis 2017; 8: 267-276.

21. Barclay LL, Kheyfets S, Zemcov A, Blass JP, McDowell FH. Risk factors in Alzheimer's disease. In: Fisher A, Hanin I, Lachman C (eds.). Alzheimer's and Parkinsons' disease. New York, Plenum Publishing 1986; 141-146.

22. Barron A, Rosario E, Elteriefi R, Pike C. Sex-specific effects of high fat diet on indices of metabolic syndrome in $3 \times T g-A D$ 
mice: Implications for Alzheimer's disease. PLoS One 2013; 8: e78554.

23. Barthet G, Dunys J, Shao ZP, Xuan Z, Ren YM, Xu JD, Arbez N, Mauger G, Bruban J, Georgakopoulos A, Shioi J, Robakis NK. Presenilin mediates neuroprotective functions of ephrin-B and brain-derived neurotrophic factor and regulates ligand-induced internalization and metabolism of EphB2 and TrkB receptors. Neurobiol Aging 2013; 34: 499-510.

24. Bartzokis G. Alzheimer's disease as homeostatic response to age-related myelin breakdown. Neurobiol Aging 2011; 32: 1341 1371

25. Beffert U, Poirier J. Apolipoprotein E, plaques, tangles and cholinergic dysfunction in Alzheimer's disease. Ann NY Acad Sc 1996; 777: 166-174

26. Bell MA, Ball MJ. Neuritic plaques and vessels of visual cortex in aging and Alzheimer's dementia. Neurobiol Aging 1990; 11 359-370.

27. Benedictus, MR, Goos JDC, Binnewwijzend MAA, Muller M, Barkhof F, Scheltens P, Prins ND, van der Flier WM. Specific risk factors for microbleeds and white matter hyperintensities for Alzheimer's disease. Neurobiol Aging 2013; 34: 2488-2494.

28. Bergeron C, Ranalli PJ, Miceli PN. Amyloid angiopathy in Alzheimer's disease. Can J Neurol Sci 1987; 14: 564-569.

29. Berr C, Hauw JJ, Delaere P, Duyckaerts C, Amouyel P. Apolipoprotein E allele 4 is linked to increased deposition of the amyloid- $\beta$-peptide $(A \beta)$ in cases with or without Alzheimer's disease. Neurosci Lett 1994; 178: 221-224.

30. Blass JP, Zemcov A. Alzheimer's disease - a metabolic systems degeneration. Neurochem Pathol 1984; 2: 103-114.

31. Bouras C, Hof PR, Morrison JH. Neurofibrillary tangle densities in the hippocampal formation in a non-demented population define subgroups of patients with differential early pathologic changes. Neurosci Lett 1993; 153: 131-135.

32. Bos I, Vos SJ, Frolich L, Kornhuber J, Wiltfang J, Maier W, Peters O, Ruther E, Engelborghs S, Niemantsverdriet E, De Roeck EE, Tsolaki M, Freund-Levim Y, Johannsen P, Vandenberghe R, Lleo A, Alcolea D, Frisoni GB, Galluzi S, Nobili F, Morbelli S, Drzrza A, Didic M, van Berckel BN, Salmon E, Bastin C, Danby S, Santana I, Baldeiras I, de Mendonica A, Silva D, Wallin A, Nordlund A, Coloma PM, Wientzek A, Alexander M, Novak GP, Gordon MF, Wallin AK, Hampel H, Soininen H, Herukka SK, Scheltens P, Verby FR, Visser PJ. The frequency and influence of dementia risk factors in prodromal Alzheimer's disease. Neurobiol Aging 2017; 56: 33-40.

33. Brun A. An overview of light and electron microscopic changes. In: Reisberg B (ed.). Alzheimer's disease. The Standard Reference. Macmillan, London and New York 1983; 37-45.

34. Burns LC, Minster RL, Demirci FY, Barmada MM, Ganguli M, Lopez OL, deKosky ST, Kamboh MI. Replication study of genome-wide associated SNPs with late-onset Alzheimer's disease. Am J Med Genet B 2011; 156B: 507-512.

35. Carbone I, Lazzarotto T, Ianni M, Porcellini E, Forti P, Masliah E, Gabrielli L, Licastro F. Herpes virus in Alzheimer's disease: related to progression of the disease. Neurobiol Aging 2014, 35: 122 129.

36. Carroll BJ. Ageing, stress and the brain. Endocrine facets of ageing. Novartis Foundation Symposium 2002; 242: 26-36.
37. Chang RCC, Ho YS, Wong S, Gentleman SM, Ng HK. Neuropathology of cigarette smoking. Acta Neuropathol 2014; 127: 53-69.

38. Chapuis J, Flaig A, Grenier-Boley B, Eysert F, Pottiez V, Deloison G, Vandeputte A, Ayral AM, Medes T, Desai S, Goate AM, Kauwe JSK, Leroux F, Herledan A, Demiautte F, Bauer C, Checler F, Petersen RC, Blennow K, Zetterberg H, Minthon L, Van Deerlin VM, Lee VMY, Shaw LM, Trojanowski JQ, Albert M, Moghekar A, O'Brien R, Peskind ER, Malmanche N, Schellenberg GD, Dourien P, Song OR, Cruchaga C, Amouyel P, deprez B, Brodin P, Lambert JC. Genome-wide, high content siRNA screening identifies the Alzheimer's genetic risk factor FERMT2 as a major modulator of APP metabolism. Acta Neuropathol 2017; 133: 955-966.

39. Chartier-Harlin MC, Crawford F, Houlden H, Warren A, Hughes D, Fidani, L, Goate A, Rossor M, Rocques P, Hardy J, Mullan M. Early onset Alzheimer's disease caused by mutations at codon 717 of the $\beta$-amyloid precursor protein gene. Nature 1991: 353: 844846.

40. Cohen D, Eisdorfer C, Walford R. Histocompatibility antigens (HLA) and patterns of cognitive loss in dementia of the Alzheimer type. Neurobiol Aging 1982; 2: 277-280.

41. Coria F, Moreno A, Rubio I, Garcia MA, Morato E, Major F. The cellular pathology associated with Alzheimer $\beta$-amyloid deposits in non-demented aged individuals. Neuropathol Appl Neurobiol 1993; 19: 261-268.

42. Delacourte A, Sergeant N, Champain D Wattez A, Maurage CA, Lebert F, Pasquier F, David JP. Nonoverlapping but synergetic tau and amyloid precursor protein pathologies in sporadic Alzheimer's disease. Neurology 2002; 59: 398-407.

43. Doruk H, Naharci MI, Bozoglu E, Isik AT, Kilic S. The relationship between body mass index and incidental mild cognitive impairment, Alzheimer's disease and vascular dementia in elderly. J Nut Health Aging 2010; 14: 834-838.

44. Doty RL, Reyes PF, Gregor T. Presence of both odour identification and detection deficits in Alzheimer's disease. Brain Res Bull 1987; 18: 597-600.

45. Du K, Liu MY, Pan YZ, Zhong X, Wei MJ. Association of serum manganese levels with Alzheimer's disease and mild cognitive impairment: A systematic review and meta-analysis. Nutrients 2017; 9: E231.

46. Eikelenboom P, Stam FC. Immunoglobulins and complement factors in senile plaques. Acta Neuropathol 1982; 57: 239-242.

47. Engelhart M. Dietary intake of antioxidants and risk of Alzheimer Disease. J Am Med Assoc 2002; 287: 3223.

48. Ferri CP, Prince M, Brayne C, Brodaty H, Fratiglioni L, Ganguly M, Hall K, Hasegawa K, Hendrie H, Huang Y, Jorm A, Mathers C, Menezes PR, Rimmer E, Scazufca M; Alzheimer's Disease International. Global prevalence of dementia: a Delphi consensus study. Lancet 2005; 366: 2112-2117.

49. Francis YI, Stephanou A, Latchman DS. CREB-binding protein activation by presenilin 1 but not by its M146L mutant. Neuroreport 2006; 17: 917-921.

50. French LR, Schuman LM, Mortimer JA, Hutton JT, Boatman RA, Christians B. A case-control study of dementia of the Alzheimer type. Am J Epidemiol 1985; 121: 414-421. 
51. Fryer JD, Taylor JW, DeMattos RB, Bates KR, Paul SM, Parsadamian M, Holtzman DM. Apolipoprotein E markedly facilitates age-dependent cerebral amyloid angiopathy and spontaneous hemorrhage in amyloid precursor protein transgenic mice. J Neurosci 2003; 23: 7889-7896.

52. Garcia-Sierra F, Hauw JJ, Duyckaerts C, Wischik CM, LunaMunoz J, Mena R. The extent of neurofibrillary pathology in perforant pathway neurons is the key determinant of dementia in the very old. Acta Neuropathol 2000; 100: 29-35.

53. Geddes J, Vowles G, Nicoll J, Revesz T. Neuronal cytoskeletal changes are an early consequence of repetitive brain injury. Acta Neuropathol 1999; 98: 171-178.

54. Gentleman SM, Nash MJ, Sweeting CJ, Graham DI, Roberts GW. $\beta$-amyloid precusor protein ( $\beta$ APP) as a marker for axonal injury after head injury. Neurosci Lett 1993; 160: 139-144.

55. Gérard H, Dreses-Werringloer U, Wildt K, Deka S, Oszust C, Balin B, Frey W, Bordayo E, Whittum-Hudson J, Hudson A. Chlamydophila (Chlamydia) pneumoniae in the Alzheimer's brain. FEMS Immunol Med Mic 2006; 48: 355-366.

56. Gessel MM, Bernstein S, Kemper M, Teplow DB, Bowers MT. Familial Alzheimer's disease mutations differentially alter amyloid beta protein oligomerization. ACS Chem Neurosci 2012; 3 : 909-918.

57. Glenner GG, Wong CW. Alzheimer's disease and Down's syndrome: sharing of a unique cerebrovascular amyloid fibril protein. Biochem Biophys Res Commun 1984; 122: 1131-1135.

58. Goate R, Chartier-Harlin MC, Mullan M, Brown J, Crawford F, Fidani L, Giuffra L, Haynes A, Irving N, James L, Mant R, Newton P, Rooke K, Roques P, Talbot C, Pericak-Vance M, Roses A, Williamson R, Rossor M, Owen M, Hardy J. Segregation of a missense mutation in the amyloid precursor protein gene with familial Alzheimer's disease. Nature 1991; 349: 704-706.

59. Goedert M, Wischik CM, Crowther RA, Walker JE, Klug A. Cloning and sequencing of the CDNA-encoding A core protein of the paired helical filament of Alzheimer-disease-Identification as the microtubule-associated protein tau. Proc Natl Acad Sci USA 1988; 85: 4051-4055.

60. Goldstein LE, Fisher AM, Tagge CA, ZhangXL, Velisek L, Sullivan JA, Upreti C, Kracht JM, Ericsson M, Wojnarowicz MW, Goletani CJ, Maglakelidze GM, casey M, Moncaster JA, Minaeva O, Moir MD, Nowinski CJ, Stern RA, Cantu RC, Geiling J, Blustajn JK, Wolozin BL, Ikezu T, Stein TD, Budson AE, Kowall NW, Chargin D, Sharon A, Samans S, Hall GF, Moss WC, Cleveland RO, Tanzi RE, Stanton PK, McKee AC. Chronic traumatic encephalopathy in blast-exposed military veterans and a blast neurotrauma mouse model. Sci Trans Med 2012; 4: 134ra60.

61. Gomez-Isla T, West HL, Rebeck GW, Harr SD, Growdon JH, Locascio JJ, Perls TT, Lipsitz LA, Hyman BT. Clinical and pathological correlates of apolipoprotein E 4 in Alzheimer's disease. Ann Neurol 1996; 39: 62-70.

62. Gosztyla ML, Brothers HM, Robinson SR. Alzheimer's amyloid-beta is an antimicrobial peptide: A review of the evidence. J Alzheimers Dis 2018; 62: 1495-1506.

63. Graeber MB, Kosel S, Egensperger R, Banati RB, Muller U, Bise K, Hoff P, Moller HJ, Fujisawa K, Mehraein P. Rediscovery of the case described by Alois Alzheimer in 1911: historical, histolog- ical and molecular genetic analysis. Neurogenetics 1997; 1: 73-80.

64. Graham DI, Gentleman SM, Lynch A, Roberts GW. Distribution of beta-amyloid protein in the brain following severe headinjury. Neuropathol Appl Neurobiol 1995; 21: 27-34.

65. Grant WB. Trends in diet and Alzheimer disease during the nutrition transition in Japan and developing countries. J Alzheimers Dis 2014; 38: 611-620.

66. Grazini M, Prabas J, Silva F, Oliveira S, Santana I, Oliveira C. Genetic basis of Alzheimer's dementia: role of mitochondrial DNA mutations. Genes Brain Behav 2006; 5 (suppl 2): 92-107.

67. Greenberg BD. The $\mathrm{COOH}$-terminus of the Alzheimer amyloid $A \beta$ peptide: Differences in length influence the process of amyloid deposition in Alzheimer brain, and tell us something about relationships among parenchymal and vessel-associated amyloid deposits. Amyloid 1995; 21: 195-203.

68. Grimm M, Mett J, Hartmann T. The impact of vitamin E and other fat-soluble vitamins on Alzheimer's disease. Int J Mol Sci 2016; 17: E1785.

69. Grudzien A, Shaw P, Wientraub S, Bigio E, Mash DC, Mesulam MM. The locus caeruleus neurofibrillary degeneration in aging, mild cognitive impairment and early Alzheimer's disease. Neurobiol Aging 2007; 28: 327-335.

70. Guillozet AL, Weintraub S, Mash DC, Mesulam MM. Neurofibrillary tangles, amyloid, and memory in aging and mild cognitive impairment. Arch Neurol 2003; 60: 729-736.

71. Gustafson DR. Adiposity hormones and dementia. J Neurol Sci 2010; 299: 30-34.

72. Hardy JA, Higgins GA. Alzheimer's disease: the amyloid cascade hypothesis. Science 1992; 256: 184-185.

73. Heinonen O, Syrjanen S, Soininen H, Talasmenii S, Kaski M, Mantyjarvi R, Syrjanen K, Riekkinen P. Circulating immune complexes in sera from patients with Alzheimer's disease, multiinfarct dementia, and Down's syndrome. Neurosci Lett 1993; 149: 67-70.

74. Helgason T. Epidemiology of mental disorder in Iceland. A geriatric follow-up (preliminary report). Ex Med Inter Cong Series 1973: 274 : 350-357.

75. Heneka MT, Nadrigny F, Regen T, Martinez-Hernandez A, Dumitrescu-Oziniek L, Terivel D, Jardanhazi-Kurutz D, Walter J, Kirchoff F, Hanisch UK, Kummer MP. Locus caeruleus controls Alzheimer's disease pathology by modulating microglial function through norepinephrine. Proc Natl Acad Sci USA 2010; 107: 6058-6063.

76. Henderson AS. The risk factors for Alzheimer's disease: a review and a hypothesis. Acta Psychiatr Scand 1988; 78: 257 275.

77. Henschke PJ, Bell DA, Cape RDT. Alzheimer's disease and HLA. Tissue Antigens 1978; 12: 132-135.

78. Herrup K. reimagining Alzheimer's disease - an age-based hypothesis. J Neurosci 2010; 30: 16755-16762.

79. Heyman A, Wilkinson WE, Hurwitz BJ, Schmechel D, Sigman AH, Weinberg T, Helms MJ, Swift M. Alzheimer's disease: genetic aspects and associated clinical disorders. Ann Neurol 1983; 14: 507-513. 
80. Heyman A, Wilkinson WE, Stafford JA, Helms MJ, Sigmon AH, Weinberg T. Alzheimer's disease: a study of epidemiological aspects. Ann Neurol 1984; 15: 335-341.

81. Hjelm C, Brostrom A, Dahl A, Johansson B, Fredrikson M, Stromberg $A$. factors associated with increased risk for dementia in individuals age 80 years or older with congestive heart failure. J Cardiovasc Nurs 2014; 29: 82-90.

82. Hoeijmakers L, Ruigrok SR, Amelianchik A, Ivan D, van Dam AM lucassen PJ, Korosi A. Early-life stress lastingly alters the neuroinflammatory response to amyloid pathology in an Alzheimer's disease mouse model. Brain Behav Immun 2017; 63 : 160-175.

83. Hoenicka J. Genes in Alzheimer's disease. Rev Neurol 2006; 42: 302-305.

84. Holm H, Nagga K, Nilsson ED, Ricci F, Melander O, Hansson O, bachus E, Magnusson M, Fedoroski A. Biomarkers of micro vascular endothelial dysfunction predict incident dementia: a population-based prospective study. J Intern Med 2017; 282 94-101.

85. Honarnejad K, Herms J. Presenilins: Role in calcium homeostasis. Int J Biochem Cell B 2012; 44: 1983-1986.

86. Hsu HW, Bondy SC, Kitazawa M. Environmental and dietary exposure to copper and its cellular mechanisms linking to Alzheimer's disease. Toxicol Sci 2018; 163: 338-345.

87. ImhofA, Kovari E, von Gunten A, Gold G, Rivara CB, Herrmann FR, Hof PR, Bouras C, Glannakopoulos P. Morphological substrates of cognitive decline in nonagenarians and centenarians: A new paradigm? J Neurol Sci 2007; 257: 72-79.

88. Ishii T, Haga S. Immuno-electron microscopic localisation of immunoglobulins in amyloid fibrils of senile plaques. Acta Neuropathol 1976; 20: 372-378.

89. Itzhaki RF. Microbes and Alzheimer's disease. J Alzheimers Dis 2016; 51: 979-984.

90. Jackson HM, Soto I, Graham LC, Carter GW, Howell GR. Clus tering of transcriptional profiles identifies changes to insulin signalling as an early event in a mouse model of Alzheimer's disease. BMC Genomics 2013; 14: 831.

91. Johnson VE, Stewart W, Smith DH. Widespread tau and amyloid-beta pathology many years after a single traumatic injury in humans. Brain Pathol 2012; 22: 142-149.

92. Jonaitis E, La Rue A, Mueller KD, Koscik RL, Hermann B, Sager MA Cognitive activities and cognitive performance in middle-aged adults at risk for Alzheimer's disease. Pyschol Aging 2013; 28 1004-1014.

93. Jordan BD. The clinical spectrum of sport-related traumatic brain injury. Nat Rev Neurol 2013; 9: 222-230.

94. Julian C, Tremblay C, Phivilay A, Berthiaume L, Emond V, Julien P, Calon F. High-fat diet aggravates amyoid-beta and tau pathologies in the 3xTg-Ad mouse model. Neurobiol Aging 2010; 31 1516-1531.

95. Kalaria RN. Vascular basis for brain degeneration: faltering controls and risk factors for dementia. Nutrition Rev 2010; 68 : S74-S87.

96. Kalaria RN, Bhatt SU, Lust WD, Perry G. The amyloid precursor protein in ischaemic brain injury and chronic hypoperfusion. Ann N Y Acad Sci 1993; 695: 190-193.
97. Kalaria R, Hedera P. Differential degeneration of the cerebral microvasculature in Alzheimer's disease. Neuroreport 1995; 6: 477-480.

98. Kappelle L, Biessels G. Increased risk of Alzheimer's disease in type II diabetes: insulin resistance of the brain or insulin-induced amyloid pathology? Biochem Soc Trans 2005; 33: 1041.

99. Karaca I, Wagner H, Ramirez A. Search for risk genes in Alzheimer's disease. Nervenarzt 2017; 88: 744-750.

100. Kieman PT, Montinegro PH, Solomon TM, McKee AC. Chronic traumatic encephalopathy: A neurodegenerative consequence of repetitive brain injury. Sem Neurol 2015; 35: 20-28.

101. Killin LO, Starr JM, Shiue IJ, Russ TC. Environmental risk factors for dementia: a systematic review. BMC Geriatrics 2016; 16: 175.

102. Kirk-Sanchez NJ, McGough EL. Physical exercises and cognitive performance in the elderly: Current perspectives. Clin Interv Aging 2014; 9: 51-62.

103. Knopman DS. An overview of common non-Alzheimer dementias. Clin Ger Med 2001; 17: 281.

104. Knopman DS, Parisi JE, Salviati A, Floriach-Robert M, Boeve BF, Ivnik RJ, Smith GE, Dickson DW, Johnson KA, Petersen LE, McDonald WC, Braak H, Petersen RC. Neuropathology of cognitively normal elderly. J Neuropathol Exp Neurol 2003; 62: 1087-1095.

105. Koldamova R, Fitz NF, Lefterov I. The role of ATP-binding cassette transporter A1 in Alzheimer's disease and neurodegeneration. Biochim Biophys Acta 2010; 1801: 824-830.

106. Kwok JBJ. Role of epigenetics in Alzheimer's and Parkinson's disease. Epigenomics 2010; 2: 671-682.

107. Lahiry DK, Maloney B. The 'LEARn' (Latent early-life associated regulation) model integrates environmental risk factors and the developmental basis of Alzheimer's disease and proposes remedial steps. Exp Gerontol 2010; 45: 291-296.

108. Lane RF, Raines SM, Steele JW, Ehrlich ME, Lah JA, Small SA, Tanzi RE, Attie AD, Gandy S. Diabetes-associated SorCS1 regulates Alzheimer's amyloid beta metabolism: Evidence for involvement of SorL1 and the retromer complex. J Neurosci 2010; 30: 13110-13115.

109. Larsson T, Sjogren T, Jacobsen O. Senile dementia: a clinical, sociomedical and genetic study. Acta Psychiatr Scand 1963; 167: 1-259.

110. Leduc V, Jasmin-Belanger S, Poirier J. APOE and cholesterol homeostasis in Alzheimer's disease. Trends Mol Sci 2010; 16: 469-477.

111. Lee CW, Shih YH, Kuo YM. Cerebrovascular pathology and amyloid plaque formation in Alzheimer's disease. Curr Alzheimers Res 2014; 11: 4-10.

112. Levy-Lahad E, Wasco W, Poorkaj P, Romano DM, Oshima J, Pettingell WH, Yu C, Paul D, Jondro PD, Schmidt SD, Wang K, Crowley AC, Fu Y, Guenette SY, Galas D, Nemens E, Wijsman EM, Bird TD, Schellenberg GD, Tanzi RE. Candidate gene for chromosome 1 familial Alzheimer's disease locus. Science 1995; 269: 973-977.

113. Li G, Shofer JB, Rhew IC, Kukuli WA, Peskind ER, McCormick W, Bowen JD, Schellenberg GD, Crane PK, Breitner JCS, Larson EB. Age-varying association between statin use and incident Alzheimer's disease. J Am Ger Soc 2010; 58: 1311-1317. 
114. Libikova H, Pogady J, Weidermann V. Search for herpetic antibodies in CSF in senile dementia and mental retardation. Acta Virol 1975; 19: 493-495. Libow LS. Epidemiology: excess mortality and proximate cause of death. In: Katzman R, Terry RD, Bick KL eds., Alzheimer's disease: senile dementia and related disorders. Aging New York, Raven Press, 1978; 7: 315-319.

115. Liu F, Pardo LM, Schuur M, Sanchez-Juan P, Isaacs A, Sleegers K, de Koning I, Zorkoltseva IV, Axenovitch TI, Witteman JCM Janssens ACJW, van Swieten JC, Aulchenko YS, Oostra BA, van Duijn CM. The apolipoprotein E gene and its age-specific effects on cognitive function. Neurobiol Aging 2010; 31: 1831 1833.

116. Liu GY, Yao LF, Liu JF, Jiang YS, Ma GD, Chen ZG, Zhao B, Li KS. Cardiovascular disease contributes to Alzheimer's disease: evidence from large-scale genome-wide association studies. Neurobiol Aging 2014; 35: 786-792.

117. Livingston G, Sommerlad A, Orgeta V, Costafreda SG, Huntley J, Ames D, Ballard C, Banerjee S, Burns J, Cooper C, Fox N, Gitlin LN, Howard R, Kales HC, Larsen EB, Rirchie K, Rockwood K, Sampson EL, Samus Q, Schneider LS, Selbaek G, Teri L, Mukadam N. Dementia prevention, intervention, and care. Lancet 2017; 390: 2673-2734.

118. Luchsinger JA. Diabetes, related conditions, and dementia. J Neurol Sci 2009; 299: 35-38.

119. Maggioli E, Boicchi C, Zorzetto M, Sinforiani E, Cereda C, Ricevuti G, Cuccia M. The human leucocyte antigen class III haplotype approach: New insights in Alzheimer's disease inflammation hypothesis. Curr Alzheimers Res 2013; 10: 1047-1058.

120. Mann DMA. The neuropathology of Alzheimer's disease: a review with pathogenetic, aetiological, and therapeutic considerations. Mech Ageing Dev 1985; 31: 213-255.

121. Mann DMA, Tucker CM, Yates PO. Topographic distribution of senile plaques, neurofibrillary tangles in the brains of non demented persons of different age. Neuropath App Neurobiol 1987; 13: 123-139.

122. Maroon JC, Winkelman R, Bost J, Amos A, Mathyssek C, Miele V. Chronic traumatic encephalopathy in contact sports: A sys tematic review of all reported pathological cases. PLoS One 2015; 10: e0117338.

123. Marottoli FM, Katsumata Y, Koster KP, Thomas R, Fardo DW, Tai LM. Peripheral inflammation, apolipoprotein E4, and amyloid-interact to induce cognitive and cerebrovascular dysfunction. ASN Neuro 2017; 9: 10.1177/1759091417719201.

124. Matsuzaki T, Sasaki K, Tanizaki Y, Hata J, Fujimi K, Matsui Y, Sekita A, Suzuki SO, Kanba S, Kiyohara Y, Iwaki T. Insulin resistance is associated with the pathology of Alzheimer disease: The Hisayama study. Neurology 2010; 75: 764-770.

125. Mazon JN, de Mello AH, Ferreira GK, Rezin GT. The impact of obesity on neurodegenerative disease. Life Sci 2017; 182 22-28.

126. McCaddon A, Kelly CL. Familial Alzheimer's disease and vitamin B12 deficiency. Age Ageing 1994; 23: 334-337.

127. McCord MC, Aizenman E. The role of intracellular zinc release in aging, oxidative stress, and Alzheimer's disease. Front Aging Neurosci 2014; 6: 77.
128. McGeer PL, McGeer EG, Kawamata T, Yamada T, Akiyama H. Reactions of the immune system in chronic degenerative neurological diseases. Can J Neurol Sci 1991; 18: 376-379.

129. Mckee AC, Stein TD, Nowinski CJ, Stern RA, Daneshvar DH, Alvarez VE, Lee HS, Hall G, Wojtowicz SM, Baugh CM, Riley DO, Kubilus CA, Cormier KA, Jacobs MA, Martin BR, Abraham CR, Ikezu T, Reichard RR, Wolozin BL, Budson AE, Goldstein LE, Kowall NW, Cantu RC. The spectrum of disease in chronic traumatic encephalopathy. Brain 2013; 136: 43-64.

130. McKee AC, Daneshvar DH, Alvarez VE, Stein TD. The neuropathology of sport. Acta Neuropathol 2014; 127: 29-51.

131. McKee AC, Stein TD, Kieman PT, Alvarez VE. The neuropathology of chronic traumatic encephalopathy. Brain Pathol 2015; 25: 350-364.

132. McKenzie JE, Gentleman SM, Roberts GW, Graham DI, Royston MC. Increased numbers of APP-immunoreactive neurons in the entorhinal cortex after head injury. Neuroreport 1994; 6: 161-164.

133. Miklossy J. Historic evidence to support a causal relationship between spirochetal infections and Alzheimer's disease. Front Aging Neurosci 2015; 7: 46

134. Miller DF, Hicks SP, D’Amato CJ, Landis JR. A descriptive study of neuritic plaques and neurofibrillary tangles in an autopsy population. Am J Epidemiol 1984; 20: 331-341.

135. Miller DL, Papayannopoulos IA, Styles J, Bobin SA, Lin YY, Biemann K, Igbal K. Peptide compositions of the cerebrovascular and senile plaque core amyloid deposits of Alzheimer's disease. Arch Biochem Biophys 1993; 301: 41-52.

136. Min JY, Min KB. Blood cadmium levels and Alzheimer's disease mortality risk in older US adults. Environ Health 2016; 15: 69.

137. Moretti R, Caruso P, Dai Ben M, Conti C, Gazzin S, Tiribelli C. Vitamin D, homocysteine, and folate in subcortical vascular dementia and Alzheimer dementia. Front Aging Neurosci 2017; 9: 169.

138. Moro ML, Giaccone G, Lombardi R, Indaco A, Uggetti A, Morbin M, Saccucci S, Di Fede G, Catania M, Walsh DM, Denmarchi A, Rozemuller A, Bogdanovic N, Bugiani F, Ghetti B, Tagliavini F. APP mutations in the $\mathrm{A}$ beta coding region are associated with abundant cerebral deposition of A beta 38. Acta Neuropathol 2012; 124: 809-821.

139. Mortimer JA, French LR, Hutton JT, Schuman LM. Head injury as a risk factor for Alzheimer's disease. Neurology 1985; 35 : 264-267.

140. Mutter J, Naumann J, Schneider R, Walach H. Mercury and Alzheimer's disease. Fortschr Neurol Psych 2007; 75: 528-540.

141. Nandy K. Immunological factors. In: Reisberg B (ed.). Alzheimer's disease. The Standard Reference. Macmillan, London and New York 1983; 135-138.

142. Notarachille G, Arnesano F, Calo V, Meleleo D. Heavy metals toxicity: effect of cadmium ions on amyloid beta protein 1-42. Possible implications for Alzheimer's disease. Biometals 2014; 27: 371-388

143. Oyama F, Shimada H, Oyama R, Ihara Y. Apolipoprotein E genotype, Alzheimer pathologies and related gene expression in the ageing population. Mol Brain Res 1995; 29: 92-98.

144. Pal A, Siotto M, Prasad R, Squitti R. Towards a unified vision of copper involvement in Alzheimer's disease: A review connect- 
ing basic, experimental, and clinical research. J Alz Dis 2015; 44: 343-354.

145. Panja F, Colacicco A, D'Introno A, Capurso C, Liaci M, Capurso S, Capurso A, Solfrizzi V. Candidate genes for late-onset Alzheimer's disease: Focus on chromosome 12. Mech Age Dev 2006; 127: 36-47.

146. Perez SE, Nadeem M, He B, Miguel JC, Malek-Ahmadi MH, Chen KW, Mufson EJ. Neocortical and hippocampal TREM2 protein levels during the progression to Alzheimer's disease. Neurobiol Aging 2017; 54: 133-143.

147. Peters S, Reid A, Fritschi L, de Klerk N, Musk AW. Long-term effects of aluminium dust inhalation. Occup Env Med 2013; 70: 864-868.

148. Piirainen S, Youssef A, song C, Kalueff AV, Landreth GE, Maim T, Tian L. Psychosocial stress on neuroinflammation and cognitive dysfunctions in Alzheimer's disease: the emerging role of microglia? Neurosci Biobehav Rev 2017; 77: 148-164.

149. Polvikoski T, Sulkava R, Haltia M, Kainulainen K, Vuorio A, Verkkoniemi A, Niinisto L, Halonen P, Kontula K. Apolipoprotein $\mathrm{E}$, dementia and cortical deposition of $\beta$-amyloid protein. N Engl J Med 1995; 333: 1242-1247.

150. Ponomareva N, Anfreeva T, Protasova M, Shagam L, Malina D, Goltsov A, Fokin V, Mitrofanov A, Rogaev E. Age-dependent effect of Alzheimer's risk variant of CLU on EEG alpha rhythm in non-demented adults. Front Aging Neurosci 2013; 5: 86.

151. Ramos-Rodriguez JJ, Spires-Jones T, Pooler AM, Lechugo-Sancho AM, Bacskai BJ, Garcia-Alloza M. Progressive neurona pathology and synaptic loss induced by prediabetes and type 2 diabetes in a mouse model of Alzheimer's disease. Mol Neurobiol 2017; 54: 3428-3438.

152. Rantanen T. Midlife fitness predicts less burden of chronic disease in later life. Clin J Sports Med 2013; 23: 499-500.

153. Regland B, Gottfries CG. The role of amyloid $\beta$-protein in Alzheimer's disease. Lancet 1992; 340: 467-469.

154. Reisberg B. Alzheimer's disease. The Standard Reference. Macmillan, London and New York 1983.

155. Richartz-Salzburger E, Stransky E, Laske C, Kohler N. Premature immunosenescence: a pathogenic factor in Alzheimer's disease. Nervenarzt 2010; 81: 837-843.

156. Roberts BR, Ryan TM, Bush Al, Masters CL, Duce JA. The role of metallobiology and amyloid- $\beta$ peptides in Alzheimer's disease. J Neurochem 2012; 120: 149-166.

157. Roberts GW, Gentleman SM, Lynch A, Murray L, Landon M, Graham DI. $\beta$-amyloid protein deposition in the brain after severe head injury: implications for the pathogenesis of Alzheimer's disease. I Neurol Neurosurg Psychiatry 1994; 57: 419-425.

158. Rogers J, Luber-Narod J. Immunoactions in nervous system: brief review with special emphasis on Alzheimer's disease. Drugs Develop Res 1988; 15: 227-235.

159. Rolim TD, Fabri GMC, Nitrini R, Anghinah R, Teixeira MJ, de Sequeira JTT, Cestari JAF, de Sequera SRDT. Oral infections and orofacial pain in Alzheimer's disease: A case-control study. J Alzheimers Dis 2014; 38: 823-829.

160. Rossor M, Mountjoy CQ. Post-mortem neurochemical changes in Alzheimer's disease compared with normal ageing. Can J Neurol Sci 1986; 13: 499-502.
161. Ruiz A, Dols-Icardo O, Bullido MJ, Pastor P, Rodríguez-Rodríguez E, López de Munain A, de Pancorbo MM, Pérez-Tur J, Alvarez V, Antonell A, López-Arrieta J, Hernández I, Tárraga L, Boada M, Lleó A, Blesa R, Frank-García A, Sastre I, Razquin C, Ortega-Cubero S, Lorenzo E, Sánchez-Juan P, Combarros O, Moreno F, Gorostidi A, Elcoroaristizabal X, Baquero M, Coto E, Sánchez-Valle R, Clarimón J; dementia genetic Spanish consortium (DEGESCO). Assessing the role of the TREM2 p.R47H variant as a risk factor for Alzheimer's disease and frontotemporal dementia. Neurobiol Aging 2014; 35: 444.e1-4.

162. Ryan J, Carriere I, Carcaillion L, Dartigues JF, Auriacombe S, Rouand O, Berr C, Ritchie K, Scarabin PY, Ancelin ML. Estrogen receptor polymorphisms and incident dementia: The prospective 3C study. Alzheimers Dement 2014; 10: 27-35.

163. Saing T, Dick M, Nelson PT, Kim RC, Cribbs DH, Head E. Frontal cortex neuropathology in dementia pugilistica. J Neurotrauma 2012; 29: 1054-1070.

164. Salazar AM, Brown P, Gajdusek DC, Gibbs CJ. Relation to Creutzfeldt-Jakob disease and other unconventional virus diseases. In: Reisberg B (ed.). Alzheimer's disease. The Standard Reference. Macmillan, London and New York 1983; 311-318.

165. Santoro A, Baibi V, Balducci E, Pirazzini C, Rosini F, Tavano F, Achilli A, Siviero P, Minicuci N, Bellavista E, Salvioli S, Marchegiani F, Cardelli M, Olivieri F, Nacmias B, Chiamenti AM, Benussi L, Chidoni R, Rose G, Gabelli C, Binetti G, Sorbi S, crepaldi G, Passarino G, Torroni A, Franceschi C. Evidence for sub-haplogroup $\mathrm{H} 5$ of mitochondrial DNA as a risk factor for late onset Alzheimer's disease. PLoS One 2010; 5: e12037.

166. Saunders A, Strittmater W, Schmechel D, St. George-Hyslop P, Pericak-Vance M, Joo S, Rose B, Gasella J, Crapper-MacLachan D, Albersts M, Hulette C, Crain B, Goldgaber D, Roses A. Association of apolipoprotein $\mathrm{E}$ allele e4 with late-onset familial and sporadic Alzheimer's disease. Neurology 1993; 43: 1467-1472.

167. Scarmeas N, Stern Y, Sergentanis T, Psaltopoulou T. Mediterranean Diet and Alzheimer's disease. Curr Alzheimers Res 2006; 12: 736-744.

168. Schreurs BG, Smith-Bell CA, Lemieux SK. Dietary cholesterol increases ventricular volume and narrows cerebrovascular diameter in a rabbit model of Alzheimer's disease. Neuroscience 2013; 254: 61-69.

169. Shalat SL, Seitzer B, Pidcock C, Baker EL. A case-control study of medical and family history and Alzheimer's disease. Am J Epidemiol 1986; 24: 540.

170. Sherrington R, Rogaev EI, Liang Y, Rogaeva EA, Levesque G, Ikeda M, Chi H, Lin C, Li G, Holman K, Tsuda T, Mar L, Foncin JF, Bruni AC, Moulese MP, Sorbi S, Rainero I, Pinessi L, Nee L, Chumakov I, Pollen D, Brookes A, Sauseau P, Polinski RJ, Wasco RJ, Dasilva HAR, Haines JL, Pericak-Vance MA, Tanzi RE, Roses AD, Fraser PE, Rommens JM and St George-Hyslop PH. Cloning of a gene bearing missense mutations in early onset familial Alzheimer's disease. Nature 1993; 375: 754-760.

171. Shetty AK, Mishra V, Kodali M, Hattiangady B. Blood brain barrier dysfunction and delayed neurological deficits in mild traumatic brain injury induced by blast shock waves. Front Cell Neurosci 2014; 8: 232. 
172. Sillen A, Forsell C, Lilius L, Axwlman K, Bjork B, Onkamo P, Kere J, Winblad B, Graff C. Genome scan on Swedish Alzheimer disease families. Mol Psychiatr 2006; 11: 182-186.

173. Soininen $\mathrm{H}$, Heinonen OP. Clinical and etiological aspects of senile dementia. Eur Neurol 1982; 21: 401-410.

174. Solas M, Aisa B, Tordera RM, Mugueta MC, Ramirez MJ. Stress contributes to the development of central insulin resistance during aging: Implication for Alzheimer's disease. BBA-Mol Basis Dis 2013; 1832: 2332-2339.

175. Soler-Lopez M, Badiola N, Zanzoni A, Aloy P. Towards Alzheimer's root cause: ECSIT as an integrating hub between oxidative stress, inflammation and mitochondrial dysfunction. Bioessays 2012; 34: 532-541.

176. Sparks DL, Scheff SW, Hunsaker JC, Liu H, Landers T, Gross DR. Induction of Alzheimer-like $\beta$-amyloid immunoreactivity in the brains of rabbits with dietary cholesterol. Exp Neurol 1994; 126: 88-94

177. Stein TD, Alvarez VE, McKee AC. Chronic traumatic encephalopathy: a spectrum of neuropathological changes following repetitive brain trauma in athletes and military personnel. Alzheimers Res Ther 2014; 6: 4.

178. Steinberg M, Hess K, Corcoran C, Mielke MM, Norton M, Breitner J, Green R, Leoutsakos J, Welsh-Bohmer K, Lyketsos C. Vas cular risk factors and neuropsychiatric symptoms in Alzheimer's disease: the Cache County Study. Int J Geriatr Psychiatry 2014; 29: 153-159.

179. Steiner H, Capell A, Leimer U, Haass C. Genes and mechanisms involved in beta-amyloid generation and Alzheimer's disease. Eur Arch Psychiatry Clin Neurosci 1999; 249: 266-270.

180. Stern RA, Daneshvar DH, Baugh CM, Selchepine DR, Montinegro PH, Riley DO, Fritts NG, Stamm JM, Robbins CA, McHale L, Simkin I, Stein TD, Alvarez VE, Goldstein LE, Budson AE, Kowall NW, Nowinski CJ, Cantu RC, McKee AC. Clinical presentation of chronic traumatic encephalopathy. Neurology 2013; 13: 1122-1129.

181. Strittmatter WJ, Wiesgraber KH, Huang DY, Dong LM, Salvesen GS, Pericak-Vance M, Schmechel D, Saunders AM, Goldgaber D, Roses D. Binding of human apolipoprotein $E$ to synthetic amyloid- $\beta$-peptide: isoform specific effects and implications for late-onset Alzheimer's disease. Proc Natl Acad Sci 1993; 90: 8098-8102.

182. Sudoh S, Kawamura Y, Sato K. Wang R, Saido TC, Oyama F, Sakaki Y, Komano H, Yanagisawa K. Presenilin-1 mutations linked to FAD increase the intracellular levels of amyloid beta protein 1-42 and its n-terminally truncated variant(s) which are generated at distinct sites. J Neurochem 1998; 71: 1535 1543.

183. Swerdlow RH. Mitochondria and cell bioenergetics: increasingly recognised components and a possible etiologic cause of Alzheimer's disease. Antioxid Redux Sign 2012; 16: 14341463.

184. Tian J, Shi J, Smallman R, Iwatsubo T, Mann D. Relationships in Alzheimer's disease between the extent of A beta deposition in cerebral blood vessel walls, as cerebral amyloid angiopathy, and the amount of cerebrovascular smooth muscle cells and collagen. Neuropathol Appl Neurobiol 2006; 32: 332-340.
185. Tolppanen AM, Ngandu T, Kareholt I, Laatikainen T, Rusanen $M$, Soininen $H$, Kivipelto $M$. Midlife and late-life body mass index and late-life dementia: Results from a prospective population-based cohort. J Alz Dis 2014; 38: 201-209.

186. Tong YW, Yang H, tian XS, Wang HC, Zhou T, Zhang SZ, Yu J, Zhang T, Fan DS, Guo XY, Tabira T, Kong FJ, Chen Z, Ziao WZ, Chin DH. High manganese, a risk for Alzheimer's disease: High manganese induces amyloid-beta related cognitive impairment. J Alzheimers Dis 2014; 42: 865-878.

187. Veerhuis R. Histological and direct evidence for the role of complement in the neuroinflammation of Alzheimer's disease. Curr Alzheimers Res 2011; 8: 34-58.

188. Veronese N, Zurio A, Soimi M, Luchini C, Trevisan C, Bano G, Manzato E, Sergi G, Rylander R. Magnesium status and Alzheimer's disease: A systematic review. Am J Alzheimers Dis 2016; 31: 208-213.

189. Von Arnim CAF, Gola U, Biesalski HK. More than the sum of its parts? Nutrition in Alzheimer's disease. Nutrition 2010; 26 : 694-700.

190. Walford RL, Fortoul T. Histocompatibility locus antigens in Alzheimer's disease. In: Reisberg B (ed.). Alzheimer's disease. The Standard Reference. Macmillan, London and New York 1983; 166-169.

191. Wallace WC, Bragin V, Robakis NK, Sambamurti K, Vanderputten D, Merril CR, Davis KL, Santucci AC Haroutunian V. Increased biosynthesis of Alzheimer amyloid precursor protein in the cerebral cortex of rats with lesions of the nucleus basalis of Meynert. Brain Res Mol Brain Res 1991; 10: 173-178.

192. Wang CY, Wang T, Zheng W, Zhao BL, Danscher G, Chen YH, Wang ZY. Zinc overload enhances APP cleavage and Abeta deposition in the Alzheimer mouse brain. PLoS One 2010; 5: e15349.

193. Wang LY, Hara K, Van Baaren JM, Price JC, Beecham GW, Gallins PJ, Whitehead PL, Wang GF, Lu CR, Slifer MA, Zuchner S, Martin ER, Mash D, Haines JL, Pericak-Vance MA, Gilbert JR. Vitamin D receptor and Alzheimer's disease: a genetic and functional study. Neurobiol Aging 2012; 33: 1844.e1-e9.

194. Wang Y, Xu SL, Liu Z, Lai C, Xie ZH, Zhao CP, Wei Y, Bi JZ. Meta-analysis on the association between the Tf gene rs1049296 and Alzheimer's disease. Can J Neurol Sci 2013; 40: 691-697.

195. Wang ZJ, Wei XM, Yang JL, Suo JN, Chen JY, Liu XC, Zhao XL. Chronic exposure to aluminium and risk of Alzheimer's disease: A meta-analysis. Neurosci Lett 2016; 610: 200-206.

196. Wang ZQ, Dong BR, Zeng G, Wang WL, Wang BY, Yuan QY. Is there an association between mild cognitive impairment and dietary pattern in Chinese elderly? Results from a cross-sectional population study. BMC Public Health 2010; 190: 595.

197. Wisniewski HM, Moretz RC, Lossinsky AS. Evidence for the induction of localised amyloid deposits and neuritic plaques by an infectious agent. Ann Neurol 1981; 10: 517-522.

198. Wisniewski T, Ghiso J, Frangione B. Alzheimer's disease and soluble A $\beta$. Neurobiol Aging 1994; 15: 143-152.

199. Wolfe MS. Processive proteolysis by gamma-secretase and the mechanism of Alzheimer's disease. Biol Chem 2012; 393: 899-905. 
200. Xu H, Finkelstein DI, Adlard PA. Interactions of metals and Apolipoprotein E in Alzheimer's disease. Front Aging Neurosci 2014; 6: 121.

201. Yu JT, Yu Y, Zhang W, Wu ZC, Li Y, Zhang N, Tan L. Single nucleotide polymorphism rs1333049 on chromosome 9p21.3 is associated with Alzheimer's disease in Han Chinese. Clin Chim Acta 2010; 411: 1204-1207.

202. Zatti G, Burgo A, Giacomello M, Barbiero L, Ghidoni R, Sinigaglia C, Florean C, Bagnoli S, Binetti G, Sorbi S, Pizzo P, Fasolata C. Presenilin mutations linked to familial Alzheimer's disease reduce endoplasmic reticulum and Golgi apparatus calcium levels. Cell Calcium 2006; 39: 539-550.

203. Zhang X, Le WD. Pathological role of hypoxia in Alzheimer's disease. Exp Neurol 2010; 223: 299-303.

204. Zhukareva V, Newell L, Lee V, Trojanoswki J. Tau isoform profile and phosphorylation state in dementia pugilistica recapitulate Alzheimer's disease. Acta Neuropathol 2001; 101: 518-524. 